\title{
ゴム製空気圧アクチュエータの制御性能*
}

\author{
則 次 俊 郎** 和 田 力**
}

\section{Control Performance of Pneumatically Driven Rubber Actuator}

\author{
Toshiro NORITSUGU, Tsutomu WADA
}

A pneumatic actuation is anticipated to be applied to more rigorous servo-type motion controls. Especially, it is possible to construct a novel flexible actuation system using the high compliance due to air compressibility. A newly developed pneumatically driven rubber actuator has been constructed for this purpose. Also, its application to robot manipulators or hands is being actively studied. However, the fundamental control characteristics are yet to be studied in depth, so the knowledge about this actuator is not sufficient for designing a servo system.

In this study, the static and dynamic characteristics are examined experimentally. Also, a position servo system was constructed with this actuator and PWM pressure control valves, of which the control performance is discussed. The principal results can be summarized as follows.

1 ) Both the displacement and the output force of this actuator are very sensitive to the operating pressure. No dynamic delay exists in the conversion process from pressure to force, and its dynamic characteristic depends only on the operating pressure response. Therefore, to apply this actuator effectively as a servo actuator, a high response and high accuracy pressure control is required.

2 ) The PWM pressure control valve with the high speed on-off solenoid valve is effective for driving this actuator.

3 ) Although this actuator has a considerablly large hysteresis, even the usual linear controller can provide the almost satisfactory control performance within this experiment.

\section{1. 緒}

近年, 空気圧アクチュエータの用途が見直され, 従 来のローコストオートメーションに対応する単純作業 だけでなく, サーボコントロールによるより高度な運 動制御への応用にも関心が高まりつつある. 特に, 空 気の圧縮性がもたらす大きなコンプライアンスを積極 的に利用することにより, 柔軟で新しいタイプの駆動 系の構築が可能になると考えられる. 最近開発された ゴム製アクチュエータ1はこのような可能性を意図し たものであり, ロボットマニピュレータやハンドへの 応用研究が盛んである ${ }^{2), 3), 4)}$. これに伴い, そのモデル 化や制御法に関する研究もいくつか報告されてい る5),6),7). しかし, このアクチュエータの基本的な制御

\footnotetext{
*平成元年11月29日 原稿受付

**岡山大学工学部

(所在地 $=700$ 岡山市津島中 $3-1-1$ )
}

性能に関する研究は不十分であり, 現状では, これを 用いたサーボ系の応答特性を前もって予測するのは容 易でない.

そこで, 本研究では, まずアクチュエータ単体の静 特性と動特性を調べ, その動作は圧力制御弁の性能に 大きく支配されることを示す.つぎに，オンオフ電磁 弁をパルス幅変調 $(\mathrm{PWM}$ ) 駆動することにより圧力制 御弁を構成し，これにより基本的な 1 自由度サーボ系 を試作する。実験によりその制御性能を調べ, ゴム製 空気圧アクチュエータを用いたサーボ系の設計指針を 明らかにする8).

\section{2.ゴム製アクチュエータの特性}

\section{1 静特性}

用いるゴム製アクチュエータは(侏)ブリ゙ススンによ り開発された製品名ラバチュエータ, 型式 SRK

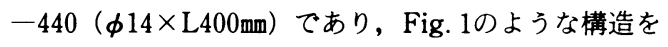
持つ.よりを施した織維コードを網状に編んだスリー 

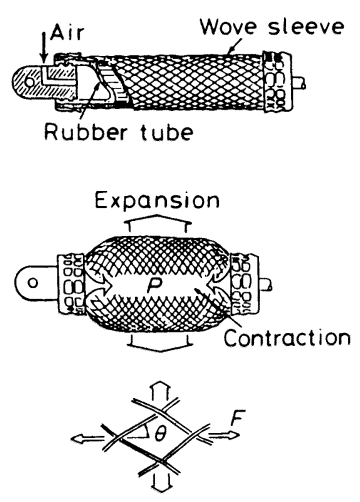

Fig. 1 Pneumatically driven rubber actuator

(quoted from Reference 1)

ブでゴム製のチューブを覆い，両端を金具で固定した ものである.チューブ内の圧力を上げると半径方向に 膨張し，このとき生じる円周方向の張力が織維コード の力変換作用によって軸方向の収縮力に変換される.

このアクチュエータについて，いくつかの仮定の下

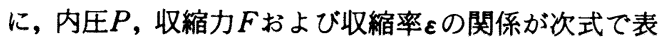
されている゙.

$$
F=\frac{\pi d_{0}^{2} P}{4 \sin ^{2} \theta_{0}}\left\{3(1-\varepsilon)^{2} \cos ^{2} \theta_{0}-1\right\}
$$

ここに, $d:$ アクュエータ直径, $L$ :アクチュエー夕 長さ, $\theta:$ 織維コードの巻き付け角度, $\varepsilon=\left(L_{0}-L\right) / L_{0}$ であり, 添字 0 は初期状態 $(P=0)$ における值を示 す.

Fig. 2は, 図中に示す要領で測定した静特性の一例 である. $P=0, F=0$ における初期長さ $L_{0}=400 \mathrm{~mm}$ 基準とする。(a)は圧力 $P$ を一定とした場合の収縮力 $F$ と収縮率 $\varepsilon=x / L_{0}$ の関係, (b)は $F$ を一定にした場合の $P$ とєの関係である.それぞれ，FおよびPを変えて $\varepsilon=$ $0 \sim 0.2$ 範囲に対して測定したものである.かなり大 きなヒステリシスが存在し，いずれの関係も非線形て あるが, 収縮率 $\varepsilon=0.1$ 付近を動作点とした場合には線 形近似もある程度妥当であることがわかる。

$\Delta x, \Delta F$ および $\Delta P$ をそれぞれ基準状態からの変化 量とすれば,

$$
\Delta x=\frac{\partial x}{\partial F} \cdot \Delta F+\frac{\partial x}{\partial P} \cdot \Delta P
$$

である. $|\partial x / \partial F|$ がこのアクチュエータのコンプラ イアンスに相当し, 内圧 $P$ が高いほどコンプライアン スは減少する。また，

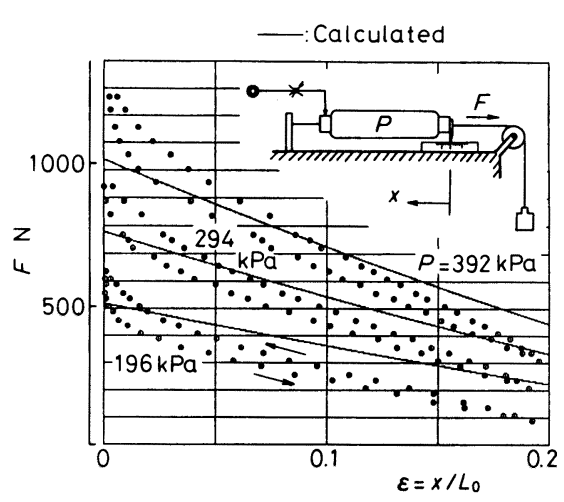

(a) Relation between displacement and force

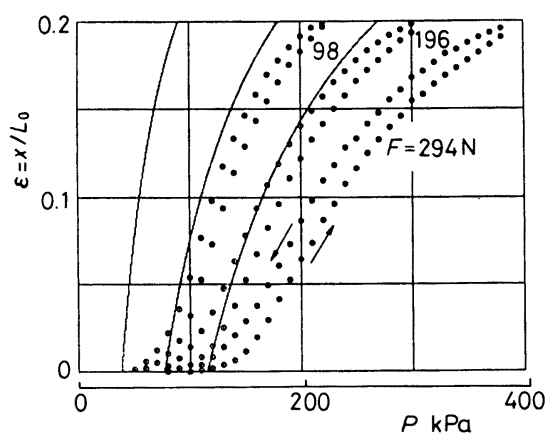

(b) Relation between operating pressure and displacement

Fig. 2 Static characteristics of actuator

$$
\begin{aligned}
\partial x / \partial P & \approx 0.5[\mathrm{~mm} / \mathrm{kPa}] \\
\delta F / \delta P & =-(\partial x / \partial P) /(\partial x / \partial F) \\
& \approx 5[\mathrm{~N} / \mathrm{kPa}]
\end{aligned}
$$

でありアクチュエータの変位量 $x$ および収縮力 $F$ は内 圧 $P$ の変化に極めて敏感である.

図中, 実線は $d_{0}=14 \mathrm{~mm}, \theta_{0}=18.5^{\circ}$ とした場合の (1) 式による計算結果である。計算值は実験值と定性的に は一致しているが, 全体的に収縮力と収縮率を過大評 価する傾向にある。これは，（1）式の導出にあたりゴ ムの弾性, 各部の摩擦などを無視したことによると考 えられる。

\section{2 動特性}

2 本のアクチュエータを用いてFig. 3(a)のような装 置を構成し, 内圧 $P$ とプーリの回転角 $\theta$ の応答からアク チュエータの応答性を評価する。本装置では, プーリ の軸まわりの慣性モーメントおよび粘性摩擦係数は十 分小さく，応答に与えるこれらの影響は無視できる。 


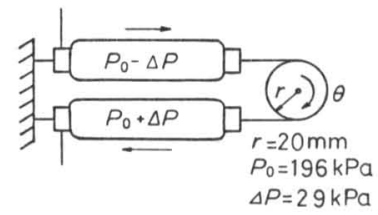

(a) Experimental setup

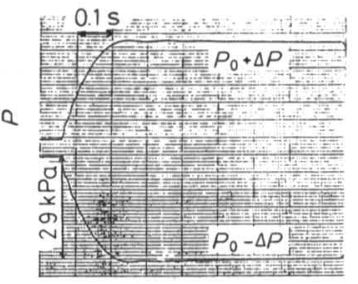

(b) Operating pressures

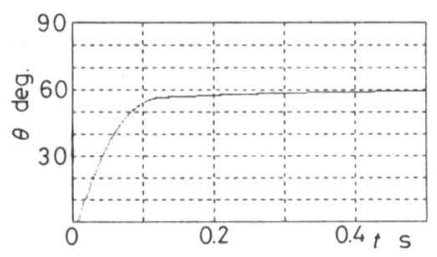

(c) Rotational angle

Fig. 3 Dynamic characteristic of actuator

(b)，(c)に示すように両者の立ち上がり時間にはほとん

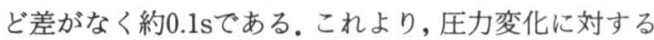
アクチュエータの応答は非常に速く，その遅れは無視 できる程度のものであることがわかる。

以上のように，ゴム製アクチュエータの動作はその 内圧に非常に敏感であり，このアクチュエータをサー ボ用アクチュエータとして効果的に利用するためには, 速応性に優れた精度の高い圧力制御が必要である。

\section{PWM圧力制御弁}

供試アクチュエータには電空サーボ弁が付属してい る.その静特性は十分満足できるものであるが，安定 性に若干問題があった.そこで, 本研究ではオンオフ 電磁弁を用いてPWM方式による圧力制御弁を新たに 構成する.オンオフ弁は有効開口面積 $1.2 \mathrm{~mm}^{2}$, 応答時間 $5 \mathrm{~ms}$ 以下 (いずれもカタログ記載値) の 2 位置 4 ポー 卜弁 4 個を並列結合して，1 組のPWM圧力制御弁と した.

Fig. 4(a)は図中に示す回路についてPWM回路も含 めた圧力制御弁の静特性を測定した結果である。 PWM回路への入力電圧 $V=0 \sim 5$ voltがデューティ $D=13 \%$ ～87\%に相当する. 搬送周波数 $f_{c}$ が低いほど, 出力圧はより広範囲の入力電圧に対して変化するが,

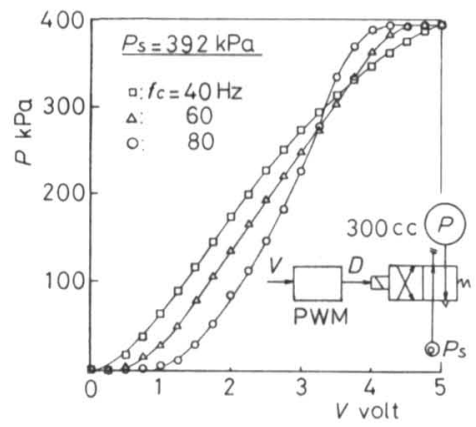

(a) Static characteristics

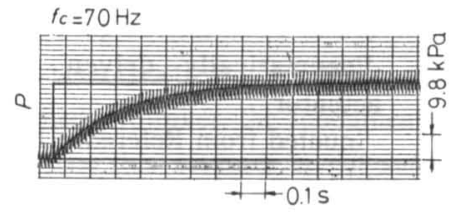

(b) Dynamic characteristic

Fig. 4 Characteristics of PWM pressure control valve

搬送波成分による圧力変動が大きくなる。逆に $f_{c}$ を高 くすると, 圧力変動は低減するが, 弁の動作遅れの影 響により比例域が狭くなる， $f_{c}$ はこれらを考慮して適 切に設定する必要がある。

Fig. 4(b)は供試アクチュエータの $\varepsilon=0.15$ 前後の容 積に相当する固定容量 $300 \mathrm{cc}$ を弁に接続した場合の圧 カのステップ応答である. $f_{c}=70 \mathrm{~Hz}$ であり, 搬送波成 分を無視した平均的な圧力変化に注目すれば, 負荷容 量を含めた弁の特性は一次遅れで近似できることがわ かる.

\section{4. 位置サーポ系の構成}

\section{1 制御系の構成}

2 本のゴム製アクチュエータと 2 組のPWM制御弁 を用いて, Fig. 5のような回転型の位置サーボ系を構

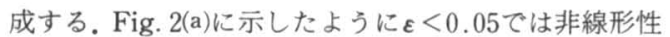
が強いので, この部分の使用を避けるため, 2 本のア クチュエータに初期圧力 $P_{0}$ をかけた状態で $\varepsilon=0.125$ となるようにワイヤの長さを調整し,この状態を基準 として $\varepsilon= \pm 0.075$ (変位にして $\pm 30 \mathrm{~mm}$ ）の部分を使用 する.プーリの直径は $40 \mathrm{~mm}$ あ゙り出力軸の可動範囲は 基準状態から $\pm 86^{\circ}$ となる. 出力軸は鉛直方向に設置す る.

角度の検出にはロータリエンコーダを使用し, カウ ンタを含めた検出部の分解能は $0.018^{\circ} /$ Pulseである. PWM制御弁の搬送周波数は $60 \mathrm{~Hz}$ とし，2つの弁は逆 


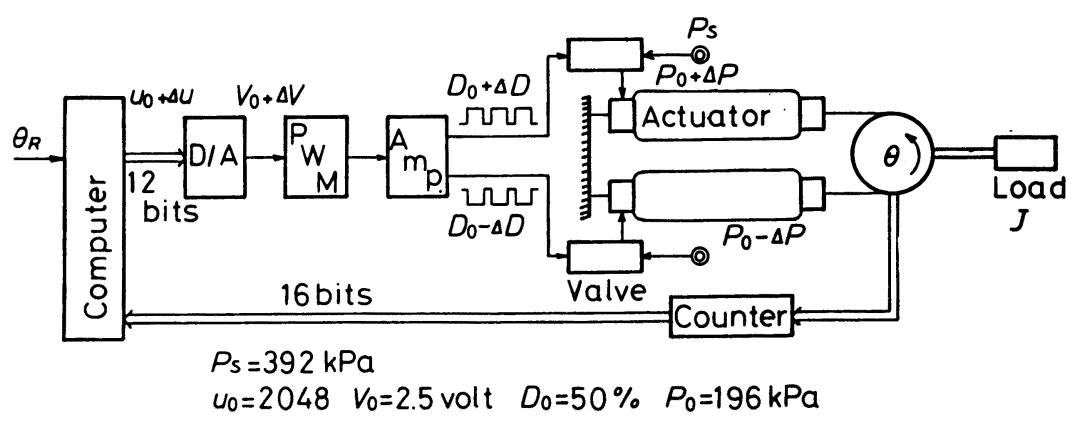

Fig. 5 Experimental position servo system

相の搬送波によって差動的に動く，図中に基準状態に おける各変数の值を示す. 計算機からの出力信号 $u=$ $u_{0}+\Delta u$ を制御入力とする.デューティ $D_{0}=50 \%$ のとき 基準圧力 $P_{0}=196 \mathrm{kPa}$ となる.

\section{2 駆動部のモデル化}

制御弁，アクチュエータおよび負荷からなる駆動部 のモデル化を行なう．アクチュエータは圧力変化に対 する応答が非常に速いので，その動特性を無視して静 特性のみを考虑すれば，以下の関係が得られる。

$$
\begin{aligned}
& J \ddot{\theta}+\dot{C \theta}=2 \Delta F \cdot r \\
& \Delta F=\frac{\partial F}{\partial P} \Delta P+\frac{\partial F}{\partial x} \Delta x \\
& \Delta x=r \theta
\end{aligned}
$$

また, Fig. 4(b)の結果よりアクチュエータの容量を含 めた弁特性は次式で表わされる。

$$
\frac{P(s)}{U(s)}=\frac{K_{a}}{1+T_{a} s}
$$

（3）〜（6）式より駆動部の特性は次式で表わされ る.

$$
\frac{\Theta(s)}{U(s)}=\frac{K \omega_{n}^{2}}{\left(1+T_{a} s\right)\left(s^{2}+2 \xi \omega_{n} s+\omega_{n}^{2}\right)}
$$

ここで,

$$
\begin{aligned}
& \omega_{n}=-\frac{2 r^{2} \partial F}{J \partial x} \\
& \xi=\frac{C}{2 \omega_{n} \cdot J} \\
& K=-\frac{K_{a} \partial F / \partial P}{r \partial F / \partial x}
\end{aligned}
$$

ここに, $J$ : 負荷の慣性モーメント, $C$ : 粘性摩擦係 数, $r$ : プーリ半径, $\theta$ : 回転角, $s$ : ラブラス演算子, $P(s)=L[\Delta P], U(s)=L[\Delta u], \Theta(s)=L[\theta]$ である.内 圧Pが高いほど, アクチュエータの剛性 $|\partial F / \partial x|$ が

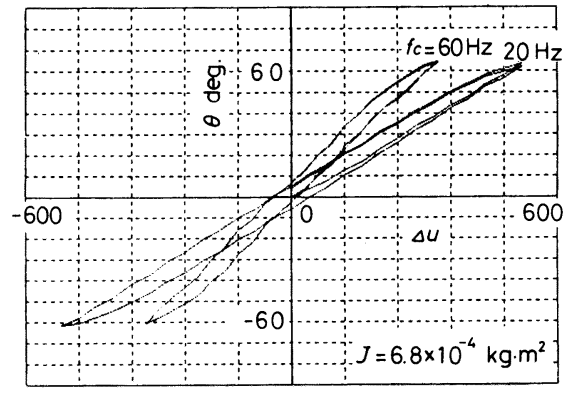

Fig. 6 Open-loop static characteristics

増加し, 固有振動数 $\omega_{n}$ が高くなる。

4.3 駆動部の特性

Fig. 5において入力 $u$ と出力軸の角変位 $\theta$ の関係を調 ベ、コム製アクチュエータとPWM圧力制御弁からな る駆動部の基本特性を明らかにする，2 種類の搬送周 波数 $f_{c}$ について，静特性の測定結果をFig. 6に示す.ア クチュエータ自体の特性に起因してヒステリシスが見 られる. $f_{c}=20 \mathrm{~Hz}$ の場合には搬送波成分による微小振 動がアクチュエータに現れ，ヒステリシスに対する ディザ効果が期待されたが，Fig. 6を見る限りその効 果はない. 以下の実験では $f_{c}=60 \mathrm{~Hz}$ とする。

Fig. 7 は 2 種類の慣性負荷Jに対する周波数応答て あり，低周波数域で回転角変化の振幅が $40^{\circ}$ となるよう な $\Delta \mathrm{u}$ をえて測定したものである.眓中の実線は, (a) では一次遅れ要素，(b)では（7）式の 3 次系による計 算值をあてはめたものである，負荷の慣性モーメント Jが小さいときには, 駆動部は一次遅れ要素として取 り扱うことができ，駆動部の特性は制御弁とアクチュ エー夕の圧力応答特性により決定されることがわかる. また，Jを考慮する場合には，（7）式の 3 次モデルが 有効である。 


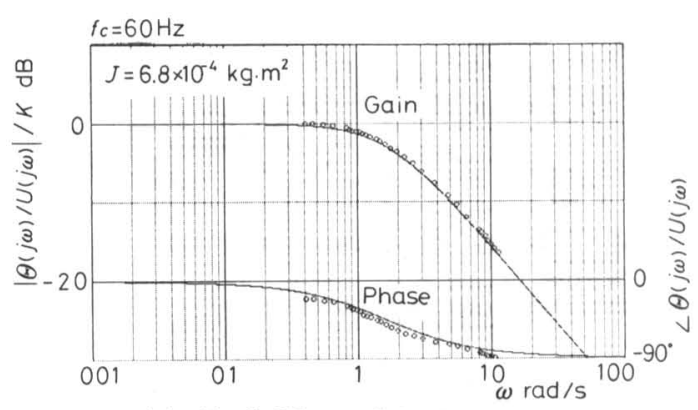

(a) Negligibly small load inertia

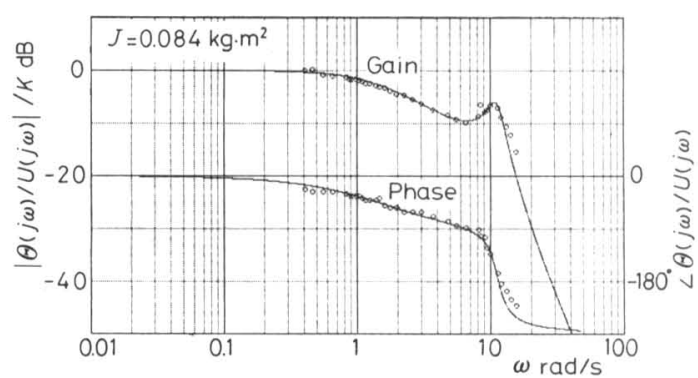

(b) Large load inertia

Fig. 7 Open-loop frequency response

Fig. 8はFig. 7と同じ慣性負荷に対してステップ応 答を測定したものである. 回転角 $\theta$ のステップ幅が $60^{\circ}$ となるような制御入力 $\Delta u$ をえた場合の, 内圧 $P$ と $\theta$ の応答を示す. (a)と(b)ではJが大きく異なるにもかか わらず応答速度はほほ同じである。これは, 本駆動部 においてはFig. 7からわかるように駆動部全体のバン ド幅が制御弁とアクチュエータの圧力応答特性によっ て決定されるためである。

\section{4 制御性能}

基本的なPID制御を用いて位置サーボ系を構成し, その制御性能を考察する. 制御則は離散化した次式を 用いる。

$$
\begin{aligned}
\Delta u(i) & =K_{P} e(i)+K_{I} \sum_{k=0}^{i} e(i) \cdot T \\
& +K_{D}\{e(i)-e(i-1)\} / T
\end{aligned}
$$

ここに, $e(i)=\theta_{R}(i)-\theta(i), T$ はサンプリング周期で あり, $\Delta u$ は計算機より出力されるディジタル量, $\theta_{R}$ と日はカウンタにより計数されるパルス数を用いて表 わす。

Fig. 7(b)に示した $J=0.084 \mathrm{~kg} \cdot \mathrm{m}^{2}$ を付加した駆動部 を制御する． $0.018^{\circ} /$ Pulseを考慮して，Fig. 6および Fig. 7(b)から読み取った開ループ系の特性（安定限界 ケ゚イン $K_{p c}=0.21$, 位相交点周波数 $11.2 \mathrm{rad} / \mathrm{s}$ ）に基づ き, 限界感度法を用いて求めた各ゲインの值をTable
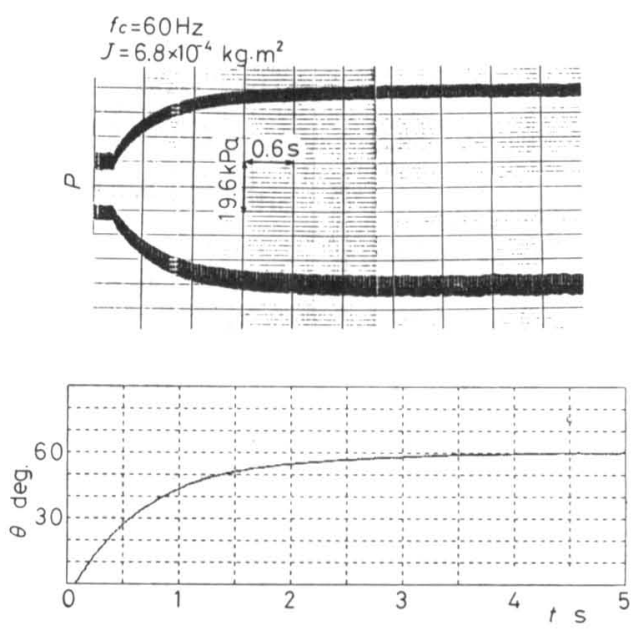

(a) Negligibly small load inertia
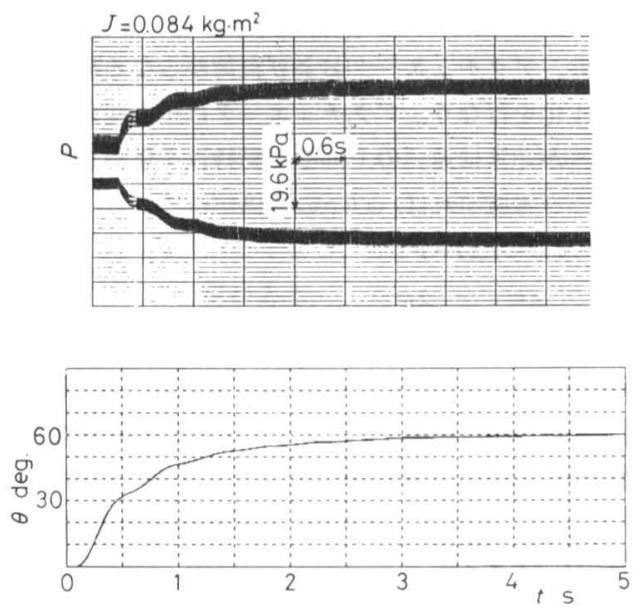

(b) Large load inertia

Fig. 8 Open-loop step responses

1に示す.

Fig. 9はステップ応答の測定結果である。制御時の サンプリング周期 $T=5 \mathrm{~ms}$ あるあ. 目標角度 $\theta_{R}=30^{\circ}$

Table 1 Estimated gains with ultimate sensitivity method

\begin{tabular}{l|ccc}
\hline & $K_{P}$ & $K_{I}$ & $K_{D}$ \\
\hline $\mathrm{P}$ & 0.105 & & \\
$\mathrm{PI}$ & 0.095 & 0.204 & \\
$\mathrm{PID}$ & 0.126 & 0.449 & 0.009 \\
\hline
\end{tabular}




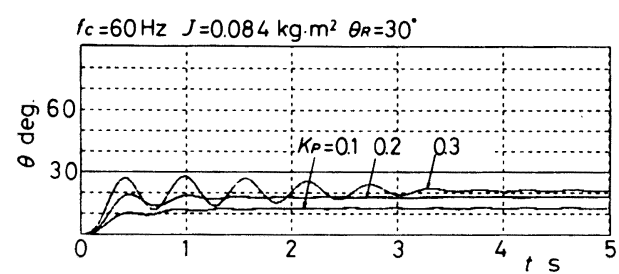

(a) P control

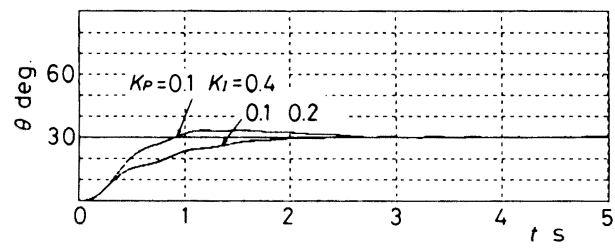

(b) PI control

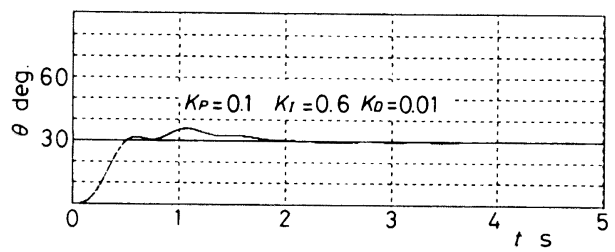

(c) PID control

Fig. 9 Closed-loop step responses

であり，P制御のみでは安定でなおかつ精度の高い制 御は不可能である.PI制御では非振動的で高精度な制 御が実現できる.さらに, PID制御を用いて速応性の改 善を試みたが，応答は(c)に示すように振動的となり， 整定時間はPI制御の場合と大差ない. Fig. 9で用いた 各ゲインの值は試行錯誤により調整したものであるが, これらは限界感度法で定めたTable 1の值にほほ近い

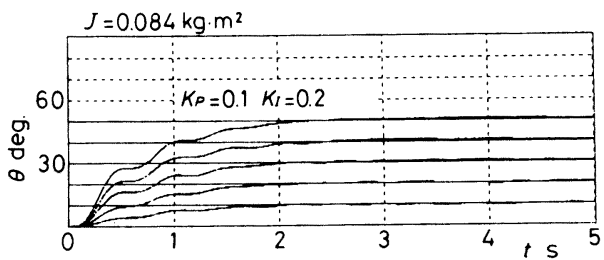

(a) PI control

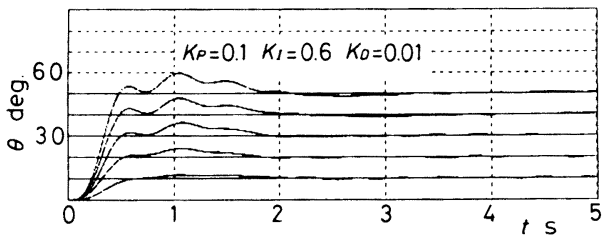

(b) PID control

Fig. 10 Closed-loop step responses for some desired values
ことがわかる.

Fig. 10 は目標角度 $\theta_{R}=10^{\circ}, 20^{\circ}, 30^{\circ}, 40^{\circ}, 50^{\circ}$ につい てPIおよびPID制御を実施した結果である.PI制御に おいては目標值を変えても大差のない応答波形が得ら れており, $\theta_{R}=0 \sim 50^{\circ}$ の範囲では同一の制御パラメー 夕でほほ満足できる制御が実現できる，安定な応答を 得るためには, PID制御に比べてPI制御の方が有利で ある。

なお，速応性に問題があるが，これを改善するため には, 制御弁とアクチュエータの圧力応答のバンド幅 が少なくとも負荷部のバンド幅を上回るように回路設 計する必要がある．このためには，本サーボ系では， PWM制御弁の開口面積（並列結合するオンオフ弁の 個数）を大きくすればよい.

アクチュエータの容量部が大きい場合, その圧力応 答の遅れがサーボ系全体の制御性能を支配することに なるので, 駆動負荷のダイナミクスを考慮した制御弁 やアクチュエータのサイズ決定が必要である.

\section{5. 結}

最近注目されているゴム製空気圧アクチュエータに ついて，その基本特性を調べた後，オンオフ電磁弁に よるPWM方式圧力制御弁を用いて位置サーボ系を構 成し, その制御性能を調べた。 その結果, 以下のこと が確認できた。

1) このアクチュエータの変位および発生力は内圧 にきわめて敏感である。また，圧力から力への変換過 程には遅れが存在せず, その動特性は空気室の圧力応 答特性に支配される。したがって，これをサーボ用ア クチュエータとして効果的に利用するためには，高精 度・高応答の圧力制御が必要である。

2 ）オンオフ電磁弁を用いたPWM圧力制御弁は高 速応答が可能であり，この種のアクチュエータ用制御 弁として有用である.

3 ) ゴム製アクチュエータにはかなり大きなヒステ リシスが存在するが，本実験の範囲では通常の線形制 御則によってもほほ満足できる制御性能を実現できる。

\section{考文献}

1 ）宇野：ゴム人工筋とロボットへの応用, 油圧と空 気圧, $17-3,175 / 180$ (1986)

2 ）橋野他：空気圧駆動介助ロボットの開発一抱き 上げマニピュレーター，第 5 回日本ロボット学 会学術講演会予稿集, 645/646 (1987)

3 ) 佐藤他：ゴム製筋肉を用いたマスタアームの開発, 第 6 回同上, 413/414（1988） 
4) 吉灌他：ゴムチューブ型人工筋を用いた 3 指ハン ドの開発，第 7 回同上, 843/844（1989）

5 ) 團山他 : 空気圧ゴム人工筋のモデル化, 第 6 回同 上, $273 / 274$ (1988)

6 ）谷口他：ゴム人工筇を用いた指機構の押し付け力 特性, 第 7 回同上, $327 / 328$ (1989)
7 ) 宮田他：空気圧ゴム人工筋の特性と制御, 日本機 械学会ロボティクス・メカトロニクス講演会'89講 演概要集, $142 / 143$ (1989)

8 ) 則次他：ゴム製空気圧アクチュエータの制御, 昭 和62年秋季油空圧講演会講演論文集, 105/ 108 (1987) 